\title{
Effect of Pruning and Drip Fertigation on Growth Parameters of Guava (Psidium guajava L.) cv. Sardar
}

\author{
A. Mahadevan ${ }^{*}$, S. Kumar ${ }^{2}$, V. Swaminathan ${ }^{3}$, A. Gurusamy ${ }^{4}$ and T. Sivakumar ${ }^{5}$ \\ ${ }^{1}$ Department of Horticulture, Krishna College of Agriculture and Technology, Srirengapuram, \\ Usilampatty, Madurai, Tamil Nadu 625532, India \\ ${ }^{2}$ Department of Horticulture, Anbil Dharmalingam Agricultural College and Research \\ Institute, Trichy, Tamil Nadu 620 009, India \\ ${ }^{3}$ Horticulture College and Research Institute, Periyakulam, Tamil Nadu 625604, India \\ ${ }^{4}$ Department of Agronomy, ${ }^{5}$ Department of Crop Physiology, Agricultural College and \\ Research Institute, Madurai, Tamil Nadu 625104, India \\ *Corresponding author
}

\begin{tabular}{|c|c|}
\hline & A B S T R A C T \\
\hline & $\begin{array}{l}\text { The guava botanically Psidium guajava belongs to family of myrtaceae. Guava was } \\
\text { considerate to be one of the most exquisite and nutritionally valuable remunerative crop. It } \\
\text { was originated in tropical America. The present investigation was conducted on "Effect of }\end{array}$ \\
\hline $\begin{array}{l}\text { Ke y w or d s } \\
\text { Guava (Psidium } \\
\text { guajava L.) cv. } \\
\text { Sardar, RDF, } \\
\text { Fertigation }\end{array}$ & $\begin{array}{l}\text { pruning and drip fertigation on growth parameters of Guava (Psidium guajava L.) cv. } \\
\text { Sardar" at Farmers Field, Devathanapatti, Theni (Dt), Tamil Nadu. The field experiment } \\
\text { was laid out in Factorial Randomized Block Design (FRBD) replicated thrice with two } \\
\text { factors (Factor 1- Pruning, Factor 2- Fertigation), i.e., different pruning levels viz., } \mathrm{P}_{0} \text { - } \\
\text { Without pruning, } \mathrm{P}_{1} \text { - Light pruning (removal of past season growth up to } 15 \mathrm{~cm} \text { ), } \mathrm{P}_{2} \text { - }\end{array}$ \\
\hline Article Info & viz., $\mathrm{F}_{0}-100$ per cent recommended dose of fertilizer (RDF) as soil application and \\
\hline $\begin{array}{l}\text { Accepted: } \\
\text { 04 July } 2018 \\
\text { Available Online: } \\
10 \text { August } 2018\end{array}$ & $\begin{array}{l}\text { fertigation, } F_{3}-75 \text { per cent RDF through fertigation, } F_{4}-50 \text { per cent RDF through } \\
\text { fertigation. The results of the investigation revealed that the morphological characters were } \\
\text { significantly influenced by different pruning levels and drip fertigation treatments. Among } \\
\text { the different pruning levels, } P_{2}-\text { moderate pruning (removal of past season growth up to } 30\end{array}$ \\
\hline & $\begin{array}{l}\mathrm{cm} \text { ) increased the tree height, tree spread, fresh weight of pruned branches and number of } \\
\text { new shoots emerged from pruned branches and shoot length resulting with earlier } \\
\text { flowering in rainy season. }\end{array}$ \\
\hline
\end{tabular}

\section{Introduction}

Guava (Psidium guajava L.), is one of the most important fruit crops cultivated widely in tropical region of the world and considered as 'poor man's apple' or 'the apple of tropics' due to its low cost of production and high nutritional value. In India, it is cultivated in an area of 0.23 million hectares with an annual production of 3.19 million tonnes and productivity of $13.6 \mathrm{t} \mathrm{ha}^{-1}$ and stands fourth place among the major tropical fruits. In Tamil 
Nadu, the area is about 0.0079 million hectares with production of 0.0978 million tonnes (NHB, 2013). The guava is almost cultivated in all the districts of Tamil Nadu with more area being concentrated in Dindigul, Madurai, Virudhunagar and Theni districts which have many factors for low productivity. Lot of scopes for increasing area under guava cultivation in Tamil Nadu in the years to come due to its demand from the consumers.

Among the many hurdles, non-adoption of canopy management is one of the reasons for low productivity in Tamil Nadu. Guava grows luxuriantly and produces abundant foliage due to its evergreen habit under tropical condition. Hence, proper training and pruning is essential to harness the sunlight vis a vis with higher productivity.

The main objective of training in guava is to produce a strong framework and scaffolding branches suitable for bearing a remunerative crop in the years to come (Anon, 1999).

Guava growers in Tamil Nadu rarely do a systematic nutrient management practice. Fertigation enables adequate supply of water and nutrients with precise manner and uniform distribution to meet the crop nutrient demand. Further, fertigation ensures substantial savings in fertilizer and water usage which reduce the leaching losses (Kumar et al., 2007). Frequent application of water and optimum split application of fertilizers in the form of fertigation improve the quality and quantity of crop yield than the conventional practice. In this connection, there is a need to adopt the precise nutrient application coupled with canopy management strategies for higher yield and quality of guava in Tamil Nadu.

\section{Materials and Methods}

The present experiment was carried out in ten years old guava trees of cv. Sardar. The spacing adopted was $6 \times 6 \mathrm{~m}$ with a plant population of 277 plants ha ${ }^{-1}$. The experiment was laid out with five levels of NPK in factorial randomized block design and replicated three times. In guava, there are three main seasons of flowering known as Ambe bahar (Feb - March), Mrig bahar (June July) and Hasta bahar (October).

The main feature of crop regulation was based on seasonal and marketable demand. In this experiment, Ambe bahar (February - March) and Mrig bahar (June - July) flowering seasons were taken for research trials and observations were recorded.

The treatment combination $\mathrm{P}_{0} \mathrm{~F}_{0}-$ Control (Without pruning + Soil application of $100 \%$ $\mathrm{RDF}), \mathrm{P}_{0} \mathrm{~F}_{1}-$ Without pruning $+125 \% \mathrm{RDF}$ through fertigation, $\mathrm{P}_{0} \mathrm{~F}_{2}$-Without pruning + $100 \%$ RDF through fertigation, $\mathrm{P}_{0} \mathrm{~F}_{3}-$ Without pruning $+75 \%$ RDF through fertigation, $\mathrm{P}_{0} \mathrm{~F}_{4}$ - Without pruning + $50 \%$ RDF through fertigation, $\mathrm{P}_{1} \mathrm{~F}_{0}-$ Removal of past season growth up to $15 \mathrm{~cm}$ (Light pruning) + Soil application of $100 \% \mathrm{RDF}, \mathrm{P}_{1} \mathrm{~F}_{1}$ - Removal of past season growth up to $15 \mathrm{~cm}$ (Light pruning) $+125 \%$ RDF through fertigation, $\mathrm{P}_{1} \mathrm{~F}_{2}$ - Removal of past season growth up to 15 $\mathrm{cm}$ (Light pruning) $+100 \%$ RDF through fertigation, $\mathrm{P}_{1} \mathrm{~F}_{3}-$ Removal of past season growth up to $15 \mathrm{~cm}$ (Light pruning) $+75 \%$ RDF through fertigation, $\mathrm{P}_{1} \mathrm{~F}_{4}-$ Removal of past season growth up to $15 \mathrm{~cm}$ (Light pruning) $+50 \%$ RDF through fertigation, $\mathrm{P}_{2} \mathrm{~F}_{0}-$ Removal of past season growth up to 30 $\mathrm{cm}$ (Moderate pruning) + Soil application of $100 \%$ RDF, $\mathrm{P}_{2} \mathrm{~F}_{1}$ - Removal of past season growth up to $30 \mathrm{~cm}$ (Moderate pruning) +125 $\%$ RDF through fertigation, $\mathrm{P}_{2} \mathrm{~F}_{2}-$ Removal of past season growth up to $30 \mathrm{~cm}$ (Moderate pruning) $+100 \%$ RDF through fertigation, $\mathrm{P}_{2} \mathrm{~F}_{3}$ - Removal of past season growth up to 30 $\mathrm{cm}$ (Moderate pruning) $+75 \%$ RDF through fertigation and $\mathrm{P}_{2} \mathrm{~F}_{4}$ - Removal of past season growth up to $30 \mathrm{~cm}$ (Moderate pruning) +50 $\%$ RDF through fertigation. 


\section{Tree height}

Tree height was measured from the ground level to growing point before pruning and after harvest and expressed in metres.

\section{Tree spread}

The spread of the tree (East to West and North to South) was measured using measuring tape in three stages before pruning, after pruning and after harvest and expressed in metre.

\section{Fresh weight of pruned branches}

The fresh branch removed from each tree at the time of pruning was taken and the value was expressed in kilograms.

Number of new shoots emerged from pruned branches

The total number of current season branches which emerged was recorded in three trees per replication and the mean value was expressed in number.

\section{Shoot length}

On the four marked branches, one on each side of the tree, five healthy shoots along with flower bud were tagged. The length of all the shoots were measured with the help of measuring tape and expressed in $\mathrm{cm}$.

\section{Statistical Analysis}

The statistical analysis of data was done by adopting the standard procedures of Panse and Sukhatme (1985)

\section{Results and Discussion}

In guava trees are training and pruning is essential to harness the sunlight concomitant with the higher productivity. Training and pruning of guava trees has been found to improve the yield and quality and provide a strong framework, Scaffolding branches are suitable for bearing a remunerative crop. Guava growers in Tamil Nadu rarely do a systematic nutrient management program. Most of them apply only FYM or poultry manure once a year after summer harvest.

However, TNAU recommends a fertilizer dose of $1.0 \mathrm{~kg}$ in each of $\mathrm{N}, \mathrm{P}$ and $\mathrm{K}$ per tree per year (Anon, 1999) and fertigation through drip system is not adopted by farmers in Tamil Nadu.

The tree height showed a linear trend of growth in all the treatments during rainy season of the study. Among the treatments, moderate pruning $(30 \mathrm{~cm})$ and application of 125 per cent RDF as WSF through fertigation recorded the highest value of plant height during rainy season while the lowest value was recorded by control (Table 1).

It has already been established that nitrogen, being an important constituent of chlorophyll, proteins and amino acids, promoted the photosynthetic efficiency of the plant system when applied at sufficient quantities (Pafli, 1965) higher rate of increase in plant height during rainy season is obvious due to the perennial nature of tree growth and the nutrients added in the first year which would have helped in assimilation of reserves in the plant leading to desirable results in the subsequent season in mango (Sivakumar, 2007).

The different level of pruning and fertigation treatments moderate pruning $(30 \mathrm{~cm})$ and application of 125 per cent RDF as WSF through fertigation recorded the increased the fresh weight of the pruned branches in rainy season (Table 2). 
Table.1 Effect of pruning and fertigation levels on tree height $(\mathrm{m})$ of guava cv. Sardar at vegetative stage

\begin{tabular}{|c|c|c|c|c|}
\hline \multicolumn{5}{|c|}{ Rainy season } \\
\hline $\begin{array}{l}\text { Pruning } \\
\text { Fertigation }\end{array}$ & $\begin{array}{c}\mathbf{P}_{\mathbf{0}} \\
\text { (No } \\
\text { pruning) }\end{array}$ & $\begin{array}{c}\text { P }_{1} \\
\text { Light } \\
\text { Pruning } \\
(15 \mathrm{~cm})\end{array}$ & $\begin{array}{c}\mathbf{P}_{2} \\
\text { Moderate } \\
\text { pruning } \\
(30 \mathrm{~cm})\end{array}$ & Mean \\
\hline$F_{0}$ (Control) & 1.79 & 1.89 & 1.95 & 1.88 \\
\hline$F_{1}(125 \%$ of RDF $)$ & 2.21 & 2.45 & 3.09 & 2.58 \\
\hline $\mathrm{F}_{2}(100 \%$ of $\mathrm{RDF})$ & 2.15 & 2.39 & 2.98 & 2.51 \\
\hline $\mathrm{F}_{3}(75 \%$ of $\mathrm{RDF})$ & 2.09 & 2.35 & 2.82 & 2.42 \\
\hline $\mathrm{F}_{4}(50 \%$ of RDF $)$ & 2.00 & 2.22 & 2.67 & 2.30 \\
\hline Mean & 2.05 & 2.26 & 2.70 & \\
\hline
\end{tabular}

\begin{tabular}{|c|c|c|c|}
\hline & P & F & P $\times$ F \\
\hline SEd & $\mathbf{0 . 0 6}$ & $\mathbf{0 . 0 4}$ & 0.07 \\
\hline CD at 5\% & 0.12 & 0.09 & 0.14 \\
\hline
\end{tabular}

Table.2 Effect of pruning and fertigation levels on fresh weight of the pruned branches (kg/plant) of guava cv. Sardar

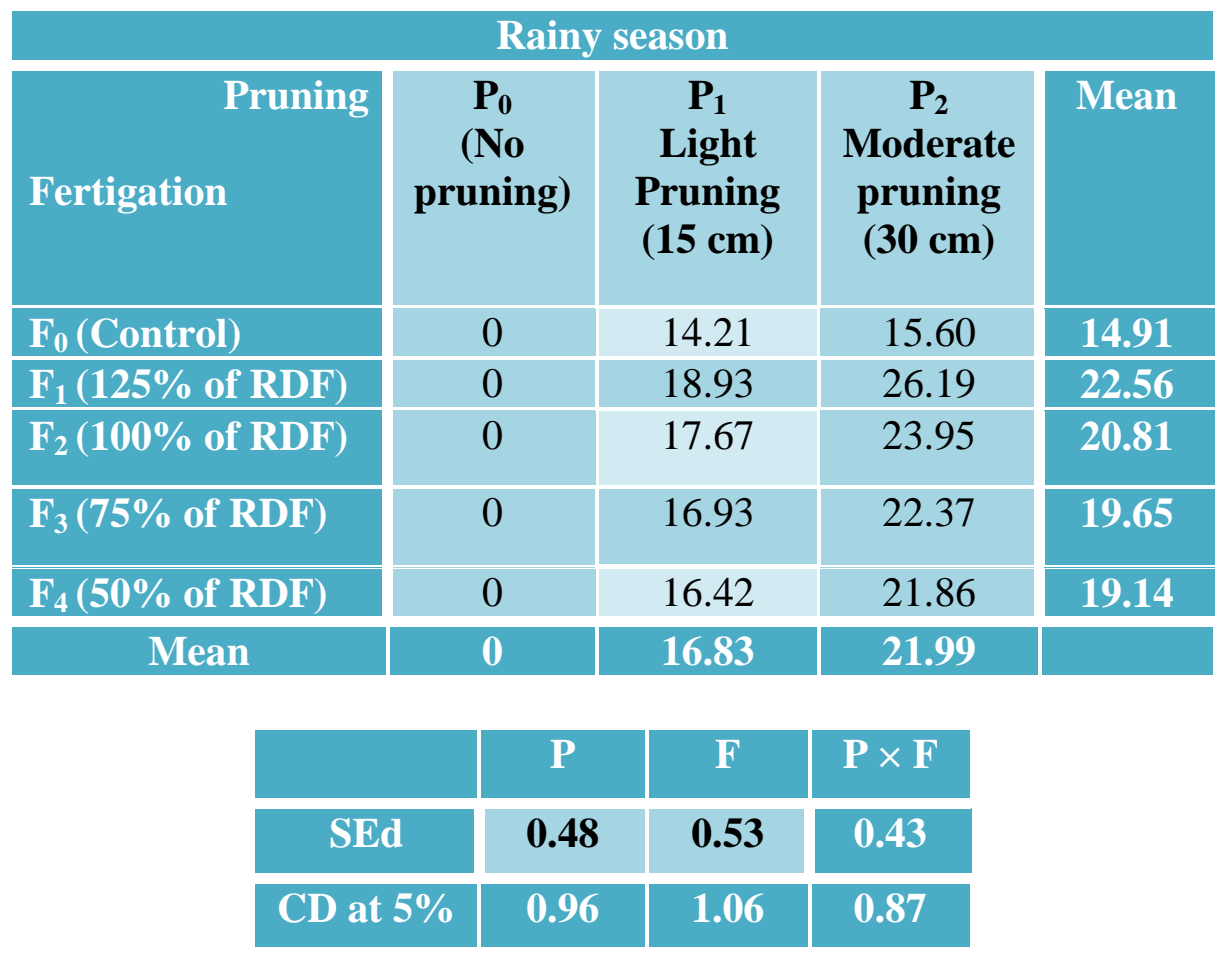


Table.3 Effect of pruning and fertigation levels on canopy spread (m) of guava cv. Sardar at vegetative stage

\begin{tabular}{|c|c|c|c|c|}
\hline \multicolumn{5}{|c|}{ Rainy season (N-S) } \\
\hline $\begin{array}{l}\text { Pruning } \\
\text { Fertigation }\end{array}$ & $\begin{array}{c}\mathbf{P}_{\mathbf{0}} \\
\text { (No } \\
\text { pruning) }\end{array}$ & $\begin{array}{c}\text { P }_{1} \\
\text { Light } \\
\text { Pruning } \\
(15 \mathrm{~cm})\end{array}$ & $\begin{array}{c}\mathbf{P}_{2} \\
\text { Moderate } \\
\text { pruning } \\
(30 \mathrm{~cm})\end{array}$ & Mean \\
\hline $\mathrm{F}_{0}($ Control $)$ & 2.44 & 2.52 & 2.55 & 2.50 \\
\hline $\mathrm{F}_{1}(125 \%$ of $\mathrm{RDF})$ & 2.70 & 2.84 & 3.05 & 2.86 \\
\hline $\mathrm{F}_{2}(100 \%$ of $\mathrm{RDF})$ & 2.65 & 2.81 & 3.00 & 2.82 \\
\hline $\mathrm{F}_{3}(75 \%$ of $\mathrm{RDF})$ & 2.61 & 2.76 & 2.94 & 2.77 \\
\hline $\mathrm{F}_{4}(50 \%$ of $\mathrm{RDF})$ & 2.57 & 2.72 & 2.89 & 2.73 \\
\hline Mean & 2.59 & 2.73 & 2.88 & \\
\hline
\end{tabular}

\begin{tabular}{|c|c|c|c|}
\hline & P & F & P $\times$ F \\
\hline SEd & $\mathbf{0 . 0 6}$ & $\mathbf{0 . 0 7}$ & 0.05 \\
\hline CD at 5\% & 0.13 & 0.15 & 0.10 \\
\hline
\end{tabular}

Table.4 Effect of pruning and fertigation levels on number of new shoot emerged from pruned branches of guava cv. Sardar

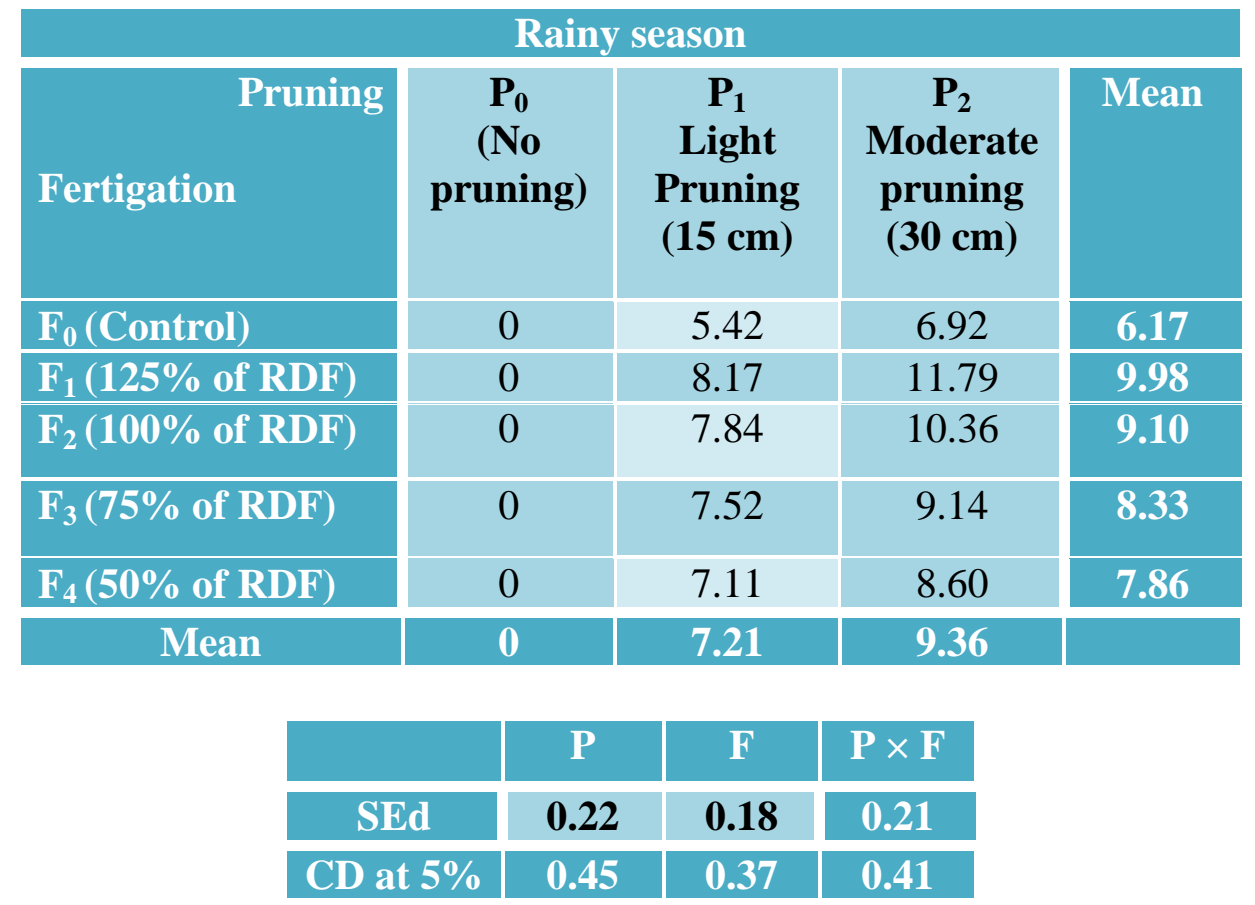


Table.5 Effect of pruning and fertigation levels on shoot length $(\mathrm{cm})$ of guava cv. Sardar

\begin{tabular}{|c|c|c|c|c|}
\hline \multicolumn{5}{|c|}{ Rainy season } \\
\hline $\begin{array}{l}\text { Pruning } \\
\text { Fertigation }\end{array}$ & $\begin{array}{c}\mathbf{P}_{0} \\
\text { (No } \\
\text { pruning) }\end{array}$ & $\begin{array}{c}\text { P }_{1} \\
\text { Light } \\
\text { Pruning } \\
(15 \mathrm{~cm})\end{array}$ & $\begin{array}{c}\mathbf{P}_{2} \\
\text { Moderate } \\
\text { pruning } \\
(30 \mathrm{~cm})\end{array}$ & Mean \\
\hline $\mathrm{F}_{0}$ (Control) & 0 & 17.01 & 18.01 & 17.51 \\
\hline$F_{1}(125 \%$ of RDF $)$ & 0 & 21.01 & 24.89 & 22.95 \\
\hline $\mathrm{F}_{2}(100 \%$ of RDF $)$ & 0 & 19.64 & 22.03 & 20.83 \\
\hline $\mathrm{F}_{3}(75 \%$ of $\mathrm{RDF})$ & 0 & 19.15 & 21.56 & 20.35 \\
\hline $\mathrm{F}_{4}(50 \%$ of $\mathrm{RDF})$ & 0 & 18.74 & 21.06 & 19.9 \\
\hline Mean & 0 & 19.11 & 21.51 & \\
\hline
\end{tabular}

\begin{tabular}{|c|c|c|c|}
\hline & P & F & P $\times$ F \\
\hline SEd & $\mathbf{0 . 5 1}$ & $\mathbf{0 . 4 6}$ & 0.56 \\
\hline CD at 5\% & 1.02 & 0.91 & 1.12 \\
\hline
\end{tabular}

The result is in line with findings of Howared Wuertz et al., (2000) who observed that drip fertigation at frequent intervals provides a consistent moisture regimes and nutrient pool in the soil and therefore, roots remain active. The proper and continuous moisture in the soil also increases the availability of nutrients and translocation of food materials which accelerate the vegetative growth of plant and maintain the micro climate of the crop at optimum level in guava.

The new shoot emergence per branches showed a linear trend of growth in all the treatments during rainy season. Among the treatments, moderate pruning $(30 \mathrm{~cm})$ and application of 125 per cent RDF as WSF through fertigation recorded the highest values of new shoots emergence during rainy season (Table 3). It may be due to the application nitrogen concomitantly which could increase vegetative growth and also might be attributed by increase in proteins and carbohydrates levels. Similar observation were made by Hillman and Galston (1961). Also increased nitrogen levels caused an increased meristemtic activity (Arney, 1951). Moreover, nitrogen is an important component of proteins, amino acids and co-enzyme which are of considerable biological importance; similar results were supported by Bhobia et al., (2005) in guava.

The shoot length showed a linear trend of growth in all the treatments with slight increment during rainy season. Among the treatments, moderate pruning $(30 \mathrm{~cm})$ and application of 125 per cent RDF as WSF through fertigation recorded the highest values of shoot length during rainy season while the lowest values were recorded by control (Table 4). It may be due to the application $\mathrm{N}$ and $\mathrm{K}$ nutrients have specific role on the apical meristematic tissue of main shoot, multiplication and differentiation process. Thus it paved the way for sprouting of discs and auxiliary buds which in turn gave raise to tillers (Yadav, 1991). Similar results were also reported by Mahendran et al., (2005) and Dhanalakshmi (1999) under drip fertigation in sugarcane.

The canopy spread showed a linear trend of growth in all the treatments during both the season of the study. Among the treatments, moderate pruning $(30 \mathrm{~cm}$ ) and application of 125 per cent RDF as WSF through fertigation 
recorded the highest values of canopy spread during rainy season while the lowest values were recorded by control (Table 5). It may be due to the application of nutrients and moisture at the appropriate time i.e rapid growth phase, which could have increased the canopy spread. Similar results were also reported by (Ramniwas et al., 2012) in guava.

Hence the present investigation clearly indicates that in moderate pruning $(30 \mathrm{~cm})$ and application of 125 per cent RDF as WSF through fertigation, the soil $\mathrm{N}$ and $\mathrm{P}$ content in fertigation treatments were higher in vegetative stage.

\section{References}

Anon.1999. Guava. Crop production techniques of Horticultural crops: 21-23.

Arney, S. E. 1952. Some effects of nitrogen nutrients on the morphological and anatomy of narrow stem kale. Ann. Appl. Biol., 39: 226-76.

Bhobia, S., K. Godara, S. Sukhbir, L. S. Beniwal and S. Kumar. 2005. Effect of organic and inorganic nitrogen yield and NPK content of guava cv. Hisar Surkha during winter season. Haryana J. Hort. Sci., 34 (3-4): 232-233.

Dhanalakshmi, M. 1999. Effect of crop geometry, drip and fertigation on yield and quality of sugarcane. M.Sc. (Ag.) Thesis. Agricultural College and Research Institute (TNAU). Madurai, Tamil Nadu.

Hillman, W. S and A.W. Galstone. 1961. The effect of external factors on auxin content. Encyclopedia of Plant Physiology.

Howard Wuertz, Sundance Farms and Ariz.2000. Subsurface Drip Irrigation:
On-Farm Responses and Technical Advances. Drip irrigating of row crops conducted on Nov. 9. In: Las Cruces, New Mexico.

Kumar, A., R. K. Singh A. K. Sinha, H. K. Singh and A. P. Mishra. 2007. Effect of fertigation on banana through drip irrigation in North Bihar. J. Res. Birsa Agric. Univ., 19:81-86.

Mahendran. S., S. Ramanathan, A. C. Prabagar, J. Stephen Arul, P. Rajarathinam and R. Yeyasrinivas. 2005. Drip and fertigation for higher cane yield. $37^{\text {th }}$ Meeting of sugarcane research and development workers of Tamil Nadu. Rajshree sugars and chemicals Ltd., Theni district. August $26^{\text {th }}$ and $27^{\text {th }}$.

Pafli, G. 1965. Relations between abundant N supply and amino acid concentration in leaves of rice plants. Plant and Soil, 23: $275-284$.

Panse, V. G and P. V. Sukhatme. 1985. Statistical Methods for Agricultural Workers. ICAR, New Delhi.

Ramniwas, R.A. Kaushik and D. K. Sarolia. 2012. Response of irrigation and fertigation scheduling on flowering, physiological parameters and fruit yield of guava (Psidium guajava L.) under high density planting. Ann. Agric. Res. New Series vol.33 (3): 115-120.

Sivakumar, V. 2007. Studies on influence of various nutrient levels applied through fertigation on growth, physiology, yield and quality of mango (Mangifera indica L.) cv. Ratna under high density planting. Ph.D. (Hort.) Thesis, Tamil Nadu Agri. Univ., Coimbatore.

Yadav, R. L. 1991. Sugarcane production technology constrains and potentialities. Oxford and IBH Pub. New Delhi.

\section{How to cite this article:}

Mahadevan, A., S. Kumar, V. Swaminathan, A. Gurusamy and Sivakumar, T. 2018. Effect of Pruning and Drip Fertigation on Growth Parameters of Guava (Psidium guajava L.) cv. Sardar. Int.J.Curr.Microbiol.App.Sci. 7(08): 65-71. doi: https://doi.org/10.20546/ijcmas.2018.708.008 